\title{
Two Patients with Complete Defects in Interferon Gamma Receptor-Dependent Signaling
}

\author{
JEROEN G. NOORDZIJ, ${ }^{1}$ NICO G. HARTWIG,${ }^{2}$ FRANK A. W. VERRECK,${ }^{4}$ SANDRA DE BRUIN-VERSTEEG,${ }^{1,2}$ \\ TJITSKE DE BOER, ${ }^{4}$ JAAP T. VAN DISSEL,${ }^{3}$ RONALD DE GROOT, ${ }^{2}$ TOM H. M. OTTENHOFF, ${ }^{4}$ and \\ JACQUES J. M. VAN DONGEN ${ }^{1,5}$
}

Received February 26, 2007; accepted April 5, 2007

Published online: 21 May 2007

Unusual susceptibility to mycobacterial infections can be caused by deleterious mutations in genes that encode the interferon- $\gamma$ receptor 1 chain. Such mutations hamper the activation of macrophages by a type 1 immune response and result in enhanced survival of intracellular pathogens. We here report two patients with unusual mycobacterial infections, both diagnosed with homozygous deleterious interferon- $\gamma$ receptor 1 gene mutations. Patient 1 became ill after Bacillus CalmetteGuérin vaccination at the age of 9 months and died at the age of 18 months. She carried a homozygous C71Y mutation in the extracellular part of the mature interferon- $\gamma$ receptor 1 protein, resulting in the lack of detectable protein expression and absence of interferon- $\gamma$ dependent signaling. Patient 2 became ill at the age of 3 years, is still alive at 19 years of age, and has suffered from five successive infection episodes with atypical mycobacteria. A homozygous splice-site mutation in intron 3 was identified, resulting in the deletion of exon 3 at the mRNA level and consequently a truncated interferon- $\gamma$ receptor 1 protein with absence of the transmembrane domain. Protein expression and interferon- $\gamma$ dependent signaling were not detectable.

KEY WORDS: Mycobacterial infection; Flow cytometric analysis; Deleterious IFNGR 1 mutations ; Splice-site mutation; ELISA.

Financial support: Revolving Fund 2000 of the Erasmus MC Rotterdam, Rotterdam, The Netherlands.

\footnotetext{
${ }^{1}$ Department of Immunology, Erasmus MC/University Medical Center Rotterdam, Rotterdam, The Netherlands.

${ }^{2}$ Department of Pediatrics, Division of Immunology and Infectious Diseases, Erasmus MC/ University Medical Center Rotterdam, Rotterdam, The Netherlands.

${ }^{3}$ Department of Infectious Diseases, Leiden University Medical Center, Leiden, The Netherlands.

${ }^{4}$ Department of Immunohematology and Blood Transfusion, Leiden University Medical Center, Leiden, The Netherlands.

${ }^{5}$ To whom correspondence should be addressed to Department of Immunology, Erasmus MC/ University Medical Center Rotterdam, Dr. Molewaterplein 50, 3015 GE Rotterdam, The Netherlands; e-mail: j.j.m.vandongen@erasmusmc.nl.
}

\section{INTRODUCTION}

The interferon- $\gamma$ receptor (IFN- $\gamma \mathrm{R}$ ) consists of two chains, the ligand-binding chain (IFN- $\gamma \mathrm{R} 1$ ), and an accessory chain (IFN- $\gamma$ R2), which is required for signal transduction. The IFN- $\gamma \mathrm{R}$ is expressed on most nucleated cells. Upon binding of IFN- $\gamma$, two IFN- $\gamma$ R1 chains will dimerize and subsequently associate with two IFN $-\gamma \mathrm{R} 2$ chains to form a tetrameric complex. The intracellular domains of IFN- $\gamma$ R 1 and 2 are constitutively bound to Janus kinases (JAK)-1 and -2 , respectively, that upon activation will phosphorylate a Tyrosine at amino acid (aa) position 440 (Y440) in the intracellular domain of IFN- $\gamma$ R1. This phosphorylation generates a docking site for signal transducer and activator of transcription (STAT) $1 \alpha$, which, in turn, becomes phosphorylated. Phosphorylated STAT1 $\alpha$ homodimers will translocate to the nucleus and bind to specific sequences in the promoter region of early IFN- $\gamma$ inducible genes (1-4). Furthermore, IFN- $\gamma$ can augment the IL-12 production by macrophages, which will stimulate T-helper 1 (Th1) and NK cells to produce IFN- $\gamma$ (4).

Intracellular signaling from the IFN $-\gamma \mathrm{R}$ is required for killing of intracellular pathogens, such as mycobacteria, by macrophages $(5,6)$. Mutations in the genes encoding the IFN- $\gamma$ R 1 or 2 chains (7-9), the $\beta 1$ chain of the IL-12R $(10,11)$, IL-12p40 (12), or STAT-1 (13), have been shown to result in enhanced susceptibility to mycobacterial infections $(14,15)$.

Mutations in the IFNGRI gene can cause either complete or partial signaling defects, resulting in two distinct phenotypes (16-18). First, patients suffering from a complete signaling defect generally present with diffuse and poorly differentiated, lepromatoid-like granulomas with many bacilli, have a poor prognosis, and can only be treated by bone marrow transplantation (BMT). Complete signaling defects can be divided into two 
Table I. Atypical Mycobacteria Cultured and Subsequent Treatment

\begin{tabular}{|c|c|c|c|c|c|}
\hline Patient & Disease episode & Age at biopsy (years) & $\begin{array}{l}\text { Culture result from } \\
\text { lymph-node biopsy }\end{array}$ & Treatment & Cured \\
\hline 1 (female) & - & 1 & M. avium & INH/ANS/ETH/CLO/MYA & No \\
\hline \multirow[t]{5}{*}{2 (male) } & 1 & 4 & M. gordonae & RIF/CIP/CLO & Yes \\
\hline & 2 & 6 & M. peregrinum & RIB/CIP/CLA/CLO & Yes \\
\hline & 3 & 16 & M. mageritense & OFL/DOX/BAC & Yes \\
\hline & 4 & 17 & M. szulgai & MER/OFL & Yes \\
\hline & 5 & 18 & M. mageritense & MER/CEF & Yes \\
\hline
\end{tabular}

Note. ANS, Ansamycin; BAC, Trimethoprim/sulphametoxazol; CEF, Cefoxitin; CIP, Ciprofloxacin; CLA, Clarithromycin; CLO, Clofazimin; DOX, Doxycyclin; ETH, Ethionamid; INH, Isoniazid; MER, Meropenem; MYA, Ethambutol; OFL, Ofloxacin; RIB, Rifabutin; RIF, Rifampicin.

subgroups, distinguishable by the absence or the presence of IFN $-\gamma$ R1 protein expression on the surface membrane (SmIFN- $\gamma$ R1). In cases with complete signaling defects but with the presence of SmIFN- $\gamma$ R1, the causative defect is in the IFN- $\gamma$ binding capacity of the IFN- $\gamma \mathrm{R}$ (18). Both subgroups show an autosomal recessive (AR) inheritance. Several reports concerning patients with complete IFN $-\gamma$ R1 deficiency have been published before (19-27).

In contrast to patients with complete IFN- $\gamma \mathrm{R} 1$ signaling defects, patients suffering from a partial IFN- $\gamma \mathrm{R} 1$ signaling defect generally present with well-circumscribed and well-differentiated tuberculoid granulomas with few visible acid-fast rods. They have a better prognosis, and may respond to treatment with IFN- $\gamma$ or antimycobacterial chemotherapy. Partial signaling defects caused by mutations in the IFNGRI gene may inherit either as an AR trait or as an autosomal dominant (AD) trait. The AR mutations generally lead to partially perturbed IFN $-\gamma \mathrm{R}$ signaling (28), The AD mutations lead to an intracellular truncated form of the IFN $-\gamma \mathrm{R} 1$ chain, which still can bind IFN- $\gamma$, but lacks intracellular signal-transducing and recycling domains, and fails to be internalized from the surface membrane (29). Thus, the $\mathrm{AD}$ form displays a dominant negative, inhibitory phenotype.

Here, we present the clinical, functional, and genetic analyses of two patients with complete IFN- $\gamma$ R1 deficiency.

\section{PATIENTS}

Patient 1 (female) had consanguineous parents of Pakistani origin. In this family, four out of eight children died, two after BCG vaccination. Her disease course was described before (30). In short, she became sick after BCG vaccination at the age of 9 months. Although a systemic BCG-itis was suspected, M. avium was cultured from peripheral blood (PB), stomach, liver, lymph node and bone. This microorganism was resistant to Isoniazid, Rifampicin, Ethambutol and Streptomycin (Table I). Sensitivity to other antimicrobial agents was not performed. Serum IgG and IgM titers against cytomegalovirus (CMV), Epstein-Barr virus (EBV), and herpes simplex virus (HSV) were negative. Serum IgG levels against HIV, Q-fever, and Toxoplasma were negative. Despite antituberculous drugs and short-term IFN- $\gamma$, she died at the age of 18 months.

Patient 2 (male) is the only child of Dutch, nonconsanguineous parents and became sick at the age of 3 years. He did not receive a BCG vaccination. $M$. gordonae, M. peregrinum, M. mageritense, M. szulgai, and $M$. mageritense were cultured from lymph-node biopsies during five consecutive independent disease episodes (Table I). These disease episodes started with malaise and weight loss, which evolved into fever and specific complaints like lymphadenopathy or arthritis (episode 4) after some weeks. During fevers, the laboratory results showed elevated inflammatory parameters like ESR and CRP in combination with leukocytosis. Ultrasound of the enlarged lymph nodes revealed central necrosis with pus that yielded a mycobacterial species after puncture and culture. After starting appropriate treatment, he responded within 2 weeks. For each disease episode he received antimicrobial therapy (Table I) varying from 6 to 9 months, depending on the speed of lymph-node resolution. At the age of 19 years, he was transferred in a good clinical condition to an infectious disease specialist for adults. At that time, he was off therapy. Serum IgG titers against different agents associated with lymphadenopathy were negative. Varicella Zoster virus (VZV) serology was compatible with a positive history for VZV infection in the past. Salmonella serology was not performed. 
All cell samples were obtained according to the informed consent guidelines of the Medical Ethics Committee of the Erasmus MC.

\section{MATERIALS AND METHODS}

\section{IFN- $\gamma$ RI Protein Expression}

Granulocytes and mononuclear cells were isolated from PB by Ficoll-Paque (density: 1.077 g/mL; Pharmacia, Uppsala, Sweden) density centrifugation. Either peripheral blood mononuclear cells (PBMC) stimulated for 3 days with PHA at a final concentration of $2 \mu \mathrm{g} / \mathrm{mL}$, or PHA-stimulated T-cell lines, from patients and controls were stained for $30 \mathrm{~min}$ at $4^{\circ} \mathrm{C}$ with specific MAb (clones from Pharmingen, San Jose, CA, or Genzyme, Cambridge, MA) or the respective isotype controls, washed, fixed, and analyzed by FACSCalibur (Becton Dickinson, San Jose, CA) for SmIFN- $\gamma$ R1 protein (CD119) expression (31).

\section{IFN- $\gamma$ Responsiveness of Cells from Patient 2}

The response of cells from patient 2 to IFN- $\gamma$ was monitored by the IFN- $\gamma$ mediated upregulation of CD64 on the PBMC-derived monocytic cell fraction as determined by flow cytometry using a CD64-specific MAb (Pharmingen).

The response of patient 2 and control cells to IFN $-\gamma$ was also analyzed by measuring the enhancement of IL-12 and TNF- $\alpha$ secretion and by the inhibition of IL-10 secretion after stimulation of whole blood cells with LPS (from $E$. coli, Sigma) at a final concentration of $100 \mathrm{ng} / \mathrm{mL}$. Briefly, $200 \mu \mathrm{L}$ of a whole blood cell suspension, that was collected in endotoxin-free tubes and five times diluted in Iscove's Modified Dulbecco's Medium (Bio-Whittaker, Verviers, Belgium), was incubated with LPS in the presence or absence of up to $1000 \mathrm{U}$ IFN- $\gamma$ (Boehringer Ingelheim). After overnight incubation, IL-12p40, TNF$\alpha$, and IL-10 were measured in the collected supernatant of three wells by ELISA (R\&D Systems) (31).

Furthermore, polymorphonuclear cells (PMN) from patient 2 were stimulated in vitro with IFN- $\gamma$ and analyzed for phosphorylation of STAT-1, binding of STAT-1 to DNA, and intracellular killing of Toxoplasma gondii and Salmonella typhimurium.

\section{STAT-1 DNA Binding Assay}

After stimulation of PMN with IFN- $\gamma(10,100,1000$, and 10,000 U) for $20 \mathrm{~min}$, cellular extracts were prepared. Protein-DNA complexes were detected by electrophoretic mobility shift assay (EMSA). Ten micrograms of extract were incubated for 30 minutes at $4^{\circ} \mathrm{C}$ in a $10 \mathrm{mM}$ Hepes buffer containing $60 \mathrm{mM} \mathrm{KCl}, 1 \mathrm{mM}$ EDTA, $1 \mathrm{mM}$ DTT, $10 \mathrm{mM} \mathrm{Na} 3 \mathrm{PO}_{4}, 10 \%$ glycerol, $1 \mu \mathrm{g}$ poly(dI-dC), $0.5 \mu \mathrm{g}$ sonicated herring sperm ssDNA, and $1 \mathrm{ng}$ of ${ }^{32} \mathrm{P}$ radiolabeled dsDNA probe corresponding to the IFN- $\gamma$ response region. Supershift experiments were performed by incubating formed complexes with STAT-1 specific antibody E23 (Santa Cruz Biotechnology, Santa Cruz, CA) for $60 \mathrm{~min}$ on ice. Samples were separated by electrophoresis on a $6 \%$ nondenaturing polyacrylamide gel. Gels were fixed with $10 \%$ methanol and $10 \%$ acetic acid, dried onto Whatmann 3M paper, and exposed to an X-ray film (31).

\section{DNA and RNA Extraction and Reverse Transcriptase Reaction}

DNA was extracted from granulocytes using the QIAamp Blood kit (Qiagen, Chatsworth, CA, USA) (32). Total RNA was isolated from PBMC according to the method of Chomczynski using RNAzol B (Tel-Test, Friendswood, TX, USA) (33). cDNA was prepared from mRNA as described before, using random hexamers and Superscript reverse transcriptase (34).

\section{PCR Amplification of (c)DNA}

PCR was performed as described previously (34). In each $100 \mu \mathrm{L}$ PCR reaction, $0.1 \mu \mathrm{g}$ (c)DNA, 20 pmol of forward and reverse oligonucleotides, and $1 \mathrm{U}$ AmpliTaq gold polymerase (Applied Biosystems, Foster City, CA, USA) were used. PCR conditions were $7 \mathrm{~min}$ at $95^{\circ} \mathrm{C}$, followed by $30 \mathrm{~s}$ at $94^{\circ} \mathrm{C}, 90 \mathrm{~s}$ at $57-60^{\circ} \mathrm{C}, 2 \mathrm{~min}$ at $72^{\circ} \mathrm{C}$ for 40 cycles, followed by a final extension step (10 min at $72^{\circ} \mathrm{C}$ ).

The sequences of the oligonucleotides used for PCR amplification of the IFNGRI gene and mRNA were based on human sequences with Genbank accession numbers AL050337 and J03143 (35), respectively, and were designed with the OLIGO 6 program (Dr. W. Rychlik, Molecular Biology Insights, Cascade, CO) (36). Primer sequences will be made available on request to interested readers.

\section{Fluorescent Sequencing Reaction and Analysis}

PCR products were first purified with the QIAquick PCR purification kit (Qiagen), and were subsequently used for sequencing with $5 \mu \mathrm{L}$ big dye terminator mix (Applied Biosystems), using 3.3 pmol sequencing primers. The sequencing primers were positioned in the IFNGRI introns sufficiently upstream and downstream of the exon-intron borders to evaluate the splice-site 
sequences. All sequencing was performed as described before (37), and run on an ABI Prism 377 fluorescent sequencer (Applied Biosystems).

\section{RESULTS}

\section{Flow Cytometric Analysis of IFN- $\gamma$ Rl Expression}

Relatively frequently, the syndrome of high susceptibility to unusual mycobacterial infections has been associated with causative, deleterious genetic mutations in the IFNGRl gene (16-18). Therefore, we screened our two patients suffering from unusual mycobacterial infections for the expression of IFN- $\gamma \mathrm{R} 1$ proteins (CD119), using two different MAb's. As shown in Fig. 1, we could not find any detectable levels of SmIFN- $\gamma \mathrm{R} 1$ protein expression on PHA blasts at day 3 after stimulation, neither on cells from patient 1 , nor on cells from patient 2 .

\section{Functional Analysis of IFN- $\gamma$ Mediated Responses}

In order to assess the capacity of cells from patient 2 to respond to IFN- $\gamma$, we monitored by flow cytometry the upregulation of CD64 (Fc $\gamma \mathrm{R} 1)$ on monocytic cells from patient 2 and controls in response to increasing doses of IFN- $\gamma$. The basal CD64 expression was normal both in the control cells as well as in the cells from patient 2. In response to IFN- $\gamma$, control cells showed normal upregulation of CD64. However, no CD64 upregulation was found in cells from patient 2 (data not shown).

Additionally, for patient 2, we performed an in vitro stimulation of whole blood cells with LPS in the presence or absence of recombinant human IFN- $\gamma$ (Fig. 2). As read-out, we measured the secreted levels of IL-12p40 or IL-10 by ELISA, which should be increased and decreased, respectively, if the IFN $-\gamma \mathrm{R}$ signaling cascade would still be intact. In accordance with the absence of detectable SmIFN- $\gamma$ R1 protein expression on patient cells and supporting the lack of CD64 upregulating-capacity, cells from patient 2 did not show an augmented IL-12p40 secretion nor an inhibited IL-10 secretion in response to IFN- $\gamma$ (Fig. 2). We also failed to detect an IFN- $\gamma$ mediated upregulation of $\mathrm{TNF}-\alpha$ production in cells from patient 2 (data not shown).

Finally, after stimulation of PMN from patient 2 with IFN- $\gamma$, we were not able to detect STAT-1 phosphorylation, binding of STAT-1 to DNA, or intracellular killing of Toxoplasma gondii or Salmonella typhimurium (data not shown).
A
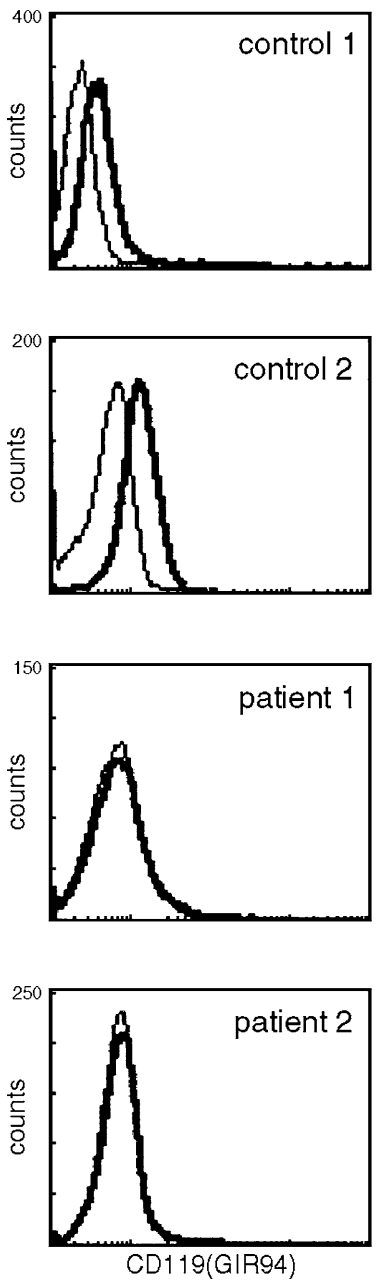

B
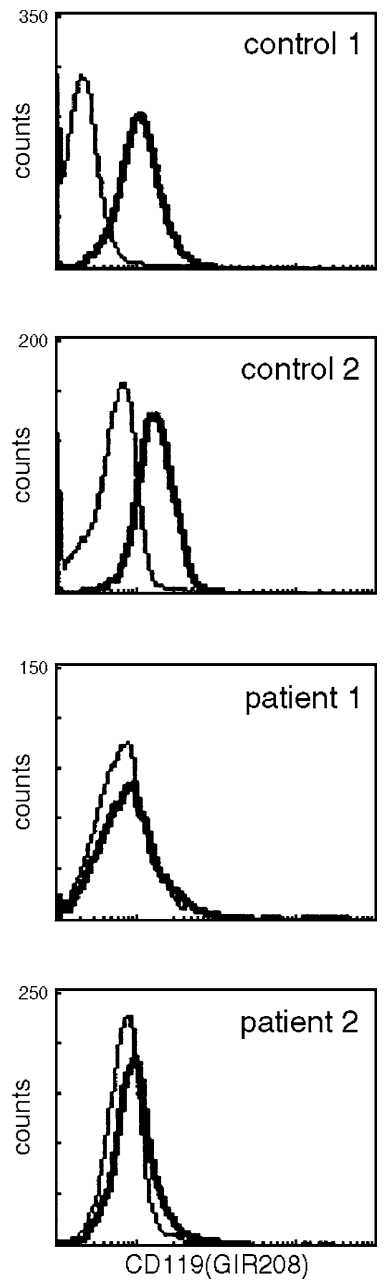

Fig. 1. Flow cytometric analysis of $I F N-\gamma R I(C D 119)$ protein expression on PHA blasts. Patient or control cells were stained with two different IFN- $\gamma$ R1 specific, nonblocking MAb's (clones from Pharmingen (A) and Genzyme (B)), and analyzed by flow cytometry. Both controls, but neither of the two patients, showed detectable levels of IFN- $\gamma$ R 1 proteins at their cell surface. Control 2 was the mother of patient 2. Shown are histograms of the fluorescent signal with isotype controls depicted by thin lines and specific staining depicted by bold lines.

\section{Characterization of IFNGRI Gene Mutations}

Since the aforementioned phenotypic and functional analyses indicated that both patient 1 and patient 2 suffered from a complete IFN- $\gamma \mathrm{R} 1$ signaling defect due to the absence of detectable SmIFN- $\gamma \mathrm{R} 1$ protein expression, we aimed at the identification of mutations in the IFNGRI gene. Sequencing of PCR products from patient 1 showed a homozygous $\mathrm{G}$ to A substitution at nucleotide position 54 in exon 3 of the IFNGRl gene (r.254G > A). This mutation was confirmed in IFNGRI-mRNA and results 
A

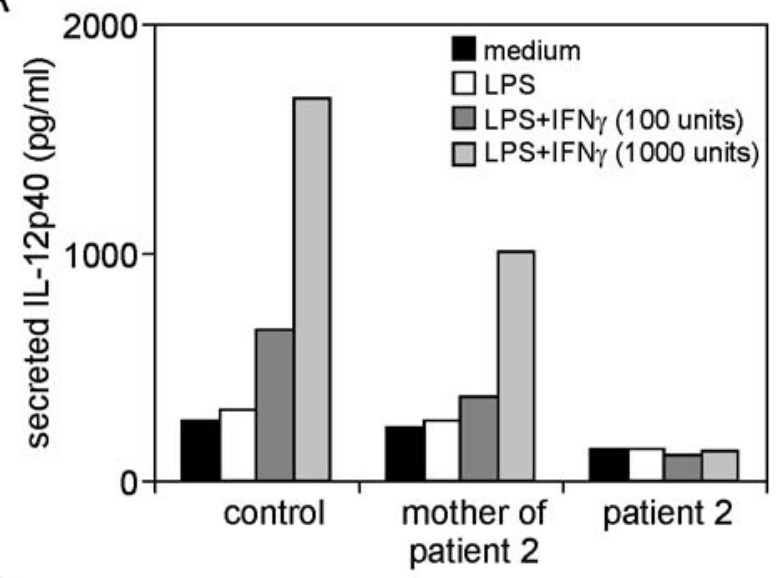

B

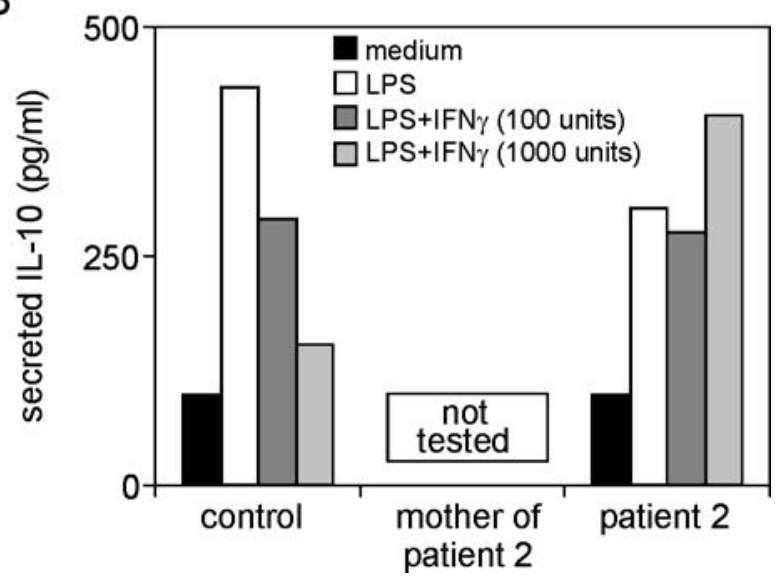

Fig. 2. Secretion of IL-12p40 and IL-10 after stimulation with $I F N-\gamma$. Whole blood cells from controls or patient 2 were tested for IFN- $\gamma$ mediated enhancement of IL-12p40 secretion or IFN- $\gamma$ mediated inhibition of IL-10 secretion upon stimulation by LPS. A. Both a healthy control and the mother of patient 2, but not patient 2 himself, showed a concentration-dependent increase in the level of secreted IL-12p40 upon LPS stimulation in the presence of IFN $-\gamma$. B. In contrast to a healthy control, patient 2 showed no concentration-dependent decrease in the amount of secreted IL-10 in the presence of IFN- $\gamma$.

in a $\mathrm{C} 71 \mathrm{Y}$ aa substitution of the mature protein. The father and mother of this patient as well as her sister were heterozygous carriers without clinical manifestations. Her brother was homozygous for the wild-type IFNGRI gene.

Sequencing of PCR products from patient 2 showed a homozygous $\mathrm{G}$ to $\mathrm{T}$ substitution at nucleotide position 1 in intron 3 of the IFNGRI gene (r.373 + $1 \mathrm{G}>\mathrm{T})$. This splice-site mutation leads to the deletion of $173 \mathrm{nu}$ cleotides starting at position 249 of the IFNGRI-mRNA (35), which corresponds to the complete absence of exon 3. This leads to a frame shift and a premature stop at codon 73 of the mature protein, with only part of the extracellular domain of the IFN- $\gamma \mathrm{R} 1$ protein translated.

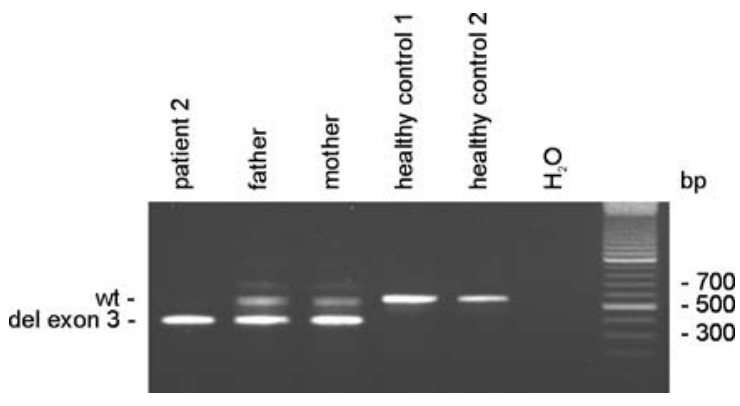

Fig. 3. RT-PCR products of IFNGRI-mRNA on agarose gel. The homozygous splice-site mutation in patient 2 leads to a complete deletion of exon 3 at the mRNA level. PBMC of his parents expressed both the wt and the mutated mRNA. Their carrier status was confirmed at the genomic DNA level.

Both nonconsanguineous parents were heterozygous for this mutation, as shown at the mRNA (Fig. 3), and the DNA level. This same mutation has been described before in a compound heterozygous child (38).

\section{DISCUSSION}

Signaling defects resulting from deleterious mutations in the IFNGRI gene can be subdivided into four groups, based on the severity of the signaling defect, the mode of inheritance, absence or presence of remaining SmIFN$\gamma \mathrm{R} 1$ proteins, and IFN- $\gamma$ binding capacity (16-18). Patients with a complete signaling defect generally have a poor prognosis, while patients with a partial signaling defect generally have a better prognosis. In this study, two patients with complete IFN- $\gamma$ R1 signaling defects were carefully analyzed, both at the molecular, biochemical, and cellular levels.

Patient 1 became ill after BCG vaccination at the age of 9 months and died at the age of 18 months. She had a homozygous $\mathrm{C} 71 \mathrm{Y}$ mutation in the mature protein. The Cysteine at aa position 71 forms an intrachain disulfide bridge with the Cysteine at aa position 63 (39).

We could not detect any IFN- $\gamma$ R 1 protein expression on PHA blasts from patient 1 (Fig. 1). However, as we used only two MAb's, the failure to detect protein expression could also be caused by changed protein conformation. This might lead to disappearance of epitopes normally recognized by our MAb. This hypothesis would be in line with the report of an IFN- $\gamma$ R1 C63Y mutation in a patient with mycobacterial infections where IFN- $\gamma$ R1 is expressed (18). Another possibility is that the C71Ymutated IFN- $\gamma$ R 1 chain becomes unstable resulting in the absence of protein expression.

It has been shown before that site-directed mutagenesis of Cysteine at position 71 and/or position 63 to Serine 
completely abolished IFN- $\gamma$ binding (39). Also the IFN- $\gamma$ R1 C63Y mutation completely abolished IFN- $\gamma$ binding (18). Based on these observations, we hypothesize that the severe clinical phenotype and the laboratory data of patient 1 with the C71Y mutation could be the result of a complete signaling defect.

Although patient 2 showed a relatively mild clinical course, we could neither detect IFN- $\gamma \mathrm{R} 1$ protein expression nor IFN- $\gamma$ mediated responses in this patient, indicative for a complete IFN- $\gamma$ R 1 signaling defect (Figs. 1 and 2). The absence of upregulation in CD64 expression and IL-12p40 production as well as the absence of downregulation in IL-10 production (Fig. 2) in response to IFN- $\gamma$, corresponds to a defect in the signaling cascade via the IFN- $\gamma$ R.

Indeed, molecular analysis of the IFNGRI gene revealed the presence of a homozygous splice-site mutation in intron 3, resulting in the absence of exon 3 at the mRNA level. The consequent premature truncation of the protein results in the absence of a large part of the extracellular domain, the complete transmembrane and all intracellular domains. This splice-site mutation has been described before in a compound heterozygous patient (38). However, splice-site mutations may allow low levels of normal splicing, resulting in the presence of wild-type (wt) mRNA (40). Such a mechanism could putatively explain the relatively mild clinical course in patient 2 . We used real-time quantitative (RQ)-PCR with specific primers for wt transcripts (40), which detected wt IFNGRI-mRNA in patient 2 after 36 cycles, corresponding to mRNA levels that were $1 \times 10^{4}$ times lower than the levels detected in a myeloid control cell line (data not shown). Such very low levels of wt IFNGRI transcripts are most likely not sufficient for explaining the relatively mild clinical course in patient 2 .

The oldest patient reported so far with a complete IFN$\gamma \mathrm{R} 1$ signaling defect is patient $20 \mathrm{q}$ described by Dorman et al. (15). In general, patients with a complete IFN- $\gamma$ R 1 signaling defect have a poor prognosis and can only be treated by bone marrow transplantation (BMT). It might be that other factors, such as genetic background or access to specialized pediatric treatment, explain the difference in clinical outcome between these patients.

In conclusion, our report confirms that deleterious IFNGRI mutations result in increased susceptibility to mycobacterial infections.

\section{ACKNOWLEDGMENTS}

The authors would like to thank Dr. M. van der Burg and Dr. E. van de Vosse for critical reading of the manuscript,
Dr. L. van der Fits for technical assistance, Dr. C. Ruwhof for helpful advice, and W. M. Comans-Bitter for design of the figures.

\section{REFERENCES}

1. Bach EA, Aguet M, Schreiber RD: The IFN gamma receptor: A paradigm for cytokine receptor signaling. Annu Rev Immunol 15:563-591, 1997

2. Boehm U, Klamp T, Groot M, Howard JC: Cellular responses to interferon-gamma. Annu Rev Immunol 15:749-795, 1997

3. Darnell JE, Jr: Studies of IFN-induced transcriptional activation uncover the Jak-Stat pathway. J Interferon Cytokine Res 18:549_ 554, 1998

4. Holland SM: Treatment of infections in the patient with Mendelian susceptibility to mycobacterial infection. Microbes Infect 2:1579_ 1590,2000

5. Huang S, Hendriks W, Althage A, Hemmi S, Bluethmann H, Kamijo $\mathrm{R}$, et al.: Immune response in mice that lack the interferon-gamma receptor. Science 259:1742-1745, 1993

6. Dalton DK, Pitts-Meek S, Keshav S, Figari IS, Bradley A, Stewart TA: Multiple defects of immune cell function in mice with disrupted interferon-gamma genes. Science 259:1739-1742, 1993

7. Newport MJ, Huxley CM, Huston S, Hawrylowicz CM, Oostra BA, Williamson $\mathrm{R}$, et al:: A mutation in the interferon-gamma-receptor gene and susceptibility to mycobacterial infection. N Engl J Med 335:1941-1949, 1996

8. Jouanguy E, Altare F, Lamhamedi S, Revy P, Emile JF, Newport M, et al:: Interferon-gamma-receptor deficiency in an infant with fatal bacille Calmette-Guerin infection. N Engl J Med 335:1956-1961, 1996

9. Dorman SE, Holland SM: Mutation in the signal-transducing chain of the interferon-gamma receptor and susceptibility to mycobacterial infection. J Clin Invest 101:2364-2369, 1998

10. de Jong R, Altare F, Haagen IA, Elferink DG, Boer T, van Breda V, et al.: Severe mycobacterial and Salmonella infections in interleukin-12 receptor-deficient patients. Science 280:14351438,1998

11. Altare F, Durandy A, Lammas D, Emile JF, Lamhamedi S, Le DF, et al.: Impairment of mycobacterial immunity in human interleukin12 receptor deficiency. Science 280:1432-1435, 1998

12. Altare F, Lammas D, Revy P, Jouanguy E, Doffinger R, Lamhamedi $S$, et al.: Inherited interleukin 12 deficiency in a child with bacille Calmette-Guerin and Salmonella enteritidis disseminated infection. J Clin Invest 102:2035-2040, 1998

13. Dupuis S, Dargemont C, Fieschi C, Thomassin N, Rosenzweig S, Harris J, et al.: Impairment of mycobacterial but not viral immunity by a germline human STAT1 mutation. Science 293:300-303, 2001

14. Ottenhoff TH, Verreck FA, Lichtenauer-Kaligis EG, Hoeve MA, Sanal O, van Dissel JT: Genetics, cytokines and human infectious disease: Lessons from weakly pathogenic mycobacteria and salmonellae. Nat Genet 32:97-105, 2002

15. Dorman SE, Picard C, Lammas D, Heyne K, van Dissel JT, Baretto $\mathrm{R}$, et al.: Clinical features of dominant and recessive interferon gamma receptor 1 deficiencies. Lancet 364:2113-2121, 2004

16. Filipe-Santos O, Bustamante J, Chapgier A, Vogt G, de BL, Feinberg $\mathrm{J}$, et al.: Inborn errors of IL-12/23- and IFN-gamma-mediated immunity: Molecular, cellular, and clinical features. Semin Immunol $18: 347-361,2006$ 
17. Rosenzweig SD, Holland SM: Defects in the interferon-gamma and interleukin-12 pathways. Immunol Rev 203:38-47, 2005

18. Jouanguy E, Dupuis S, Pallier A, Doffinger R, Fondaneche MC, Fieschi C, et al.: In a novel form of IFN-gamma receptor 1 deficiency, cell surface receptors fail to bind IFN-gamma. J Clin Invest 105:1429-1436, 2000

19. Allende LM, Lopez-Goyanes A, Paz-Artal E, Corell A, GarciaPerez MA, Varela P, et al.: A point mutation in a domain of gamma interferon receptor 1 provokes severe immunodeficiency. Clin Diagn Lab Immunol 8:133-137, 2001

20. Cunningham JA, Kellner JD, Bridge PJ, Trevenen CL, Mcleod DR, Davies HD: Disseminated bacille Calmette-Guerin infection in an infant with a novel deletion in the interferon-gamma receptor gene. Int J Tuberc Lung Dis 4:791-794, 2000

21. Rosenzweig S, Dorman SE, Roesler J, Palacios J, Zelazko M, Holland SM: 561del4 defines a novel small deletion hotspot in the interferon-gamma receptor 1 chain. Clin Immunol 102:25-27, 2002

22. Dorman SE, Uzel G, Roesler J, Bradley JS, Bastian J, Billman G, et al.: Viral infections in interferon-gamma receptor deficiency. $\mathrm{J}$ Pediatr 135:640-643, 1999

23. Holland SM, Dorman SE, Kwon A, Pitha-Rowe IF, Frucht DM, Gerstberger SM, et al.: Abnormal regulation of interferon-gamma, interleukin-12, and tumor necrosis factor-alpha in human interferongamma receptor 1 deficiency. J Infect Dis 178:1095-1104, 1998

24. Altare F, Jouanguy E, Lamhamedi-Cherradi S, Fondaneche MC, Fizame C, Ribierre F, et al.: A causative relationship between mutant IFNgR1 alleles and impaired cellular response to IFNgamma in a compound heterozygous child. Am J Hum Genet 62:723-726, 1998

25. Ward CM, Jyonouchi H, Kotenko SV, Smirnov SV, Patel R, Aguila $\mathrm{H}$, et al.: Adjunctive treatment of disseminated Mycobacterium avium complex infection with interferon alpha- $2 b$ in a patient with complete interferon-gamma receptor R1 deficiency. Eur J Pediatr 2006 [Epub ahead of print]

26. Camcioglu Y, Picard C, Lacoste V, Dupuis S, Akcakaya N, Cokura $\mathrm{H}$, et al.: HHV-8-associated Kaposi sarcoma in a child with IFNgammaR1 deficiency. J Pediatr 144:519-523, 2004

27. Reuter U, Roesler J, Thiede C, Schulz A, Classen CF, Oelschlagel $\mathrm{U}$, et al.: Correction of complete interferon-gamma receptor 1 deficiency by bone marrow transplantation. Blood 100:4234-4235, 2002

28. Jouanguy E, Lamhamedi-Cherradi S, Altare F, Fondaneche MC, Tuerlinckx D, Blanche S, et al.: Partial interferon-gamma receptor 1 deficiency in a child with tuberculoid bacillus Calmette-Guerin infection and a sibling with clinical tuberculosis. J Clin Invest 100:2658-2664, 1997

29. Jouanguy E, Lamhamedi-Cherradi S, Lammas D, Dorman SE, Fondaneche MC, Dupuis S, et al.: A human IFNGR1 small deletion hotspot associated with dominant susceptibility to mycobacterial infection. Nat Genet 21:370-378, 1999
30. de Groot R, van Dongen JJ, Neijens HJ, Hooijkaas H, Drexhage HA: Familial disseminated atypical mycobacterial infection in childhood. Lancet 345:993, 1995

31. Janssen R, van Wengen A, Verhard E, de Boer T, Zomerdijk T, Ottenhoff THM, van Dissel JT: Divergent role for TNF- $\alpha$ in IFN- $\gamma$ induced killing of Toxoplasma gondii and Salmonella typhimurium contributes to selective susceptibility of patients with partial IFN- $\gamma$ receptor 1 deficiency. J Immunol 169:3900-3907, 2002

32. Verhagen OJ, Wijkhuijs AJ, Van Der Sluijs-Gelling AJ, Szczepanski T, Van Der Linden-Schrever BE, Pongers-Willemse MJ, et al.: Suitable DNA isolation method for the detection of minimal residual disease by PCR techniques. Leukemia 13:1298-1299, 1999

33. Chomczynski P, Sacchi N: Single-step method of RNA isolation by acid guanidinium thiocyanate-phenol-chloroform extraction. Anal Biochem 162:156-159, 1987

34. van Dongen JJ, Macintyre EA, Gabert JA, Delabesse E, Rossi V, Saglio G, et al.: Standardized RT-PCR analysis of fusion gene transcripts from chromosome aberrations in acute leukemia for detection of minimal residual disease. Report of the BIOMED-1 concerted action: Investigation of minimal residual disease in acute leukemia. Leukemia 13:1901-1928, 1999

35. Aguet M, Dembic Z, Merlin G: Molecular cloning and expression of the human interferon-gamma receptor. Cell 55:273-280, 1988

36. Pongers-Willemse MJ, Verhagen OJ, Tibbe GJ, Wijkhuijs AJ, de Haas V, Roovers E, et al:: Real-time quantitative PCR for the detection of minimal residual disease in acute lymphoblastic leukemia using junctional region specific TaqMan probes. Leukemia 12:20062014, 1998

37. Szczepanski T, Pongers-Willemse MJ, Langerak AW, Harts WA, Wijkhuijs AJ, van Wering ER, et al.: Ig heavy chain gene rearrangements in T-cell acute lymphoblastic leukemia exhibit predominant DH6-19 and DH7-27 gene usage, can result in complete V-D-J rearrangements, and are rare in T-cell receptor alpha beta lineage. Blood 93:4079-4085, 1999

38. Roesler J, Kofink B, Wendisch J, Heyden S, Paul D, Friedrich W, et al.: Listeria monocytogenes and recurrent mycobacterial infections in a child with complete interferon-gamma-receptor (IFNgammaR1) deficiency: Mutational analysis and evaluation of therapeutic options. Exp Hematol 27:1368-1374, 1999

39. Stuber D, Friedlein A, Fountoulakis M, Lahm HW, Garotta G: Alignment of disulfide bonds of the extracellular domain of the interferon gamma receptor and investigation of their role in biological activity. Biochemistry 32:2423-2430, 1993

40. Noordzij JG, de Bruin-Versteeg S, Hartwig NG, Weemaes CM, Gerritsen EJ, Bernatowska E, et al.: XLA patients with BTK splicesite mutations produce low levels of wild-type BTK transcripts. J Clin Immunol 22:306-318, 2002 